ARTUR GRZĄDZIEL

Hydrographic Support Squadron of the Polish Navy, Gdynia, Poland

MARIUSZ WĄŻ

Polish Naval Academy, Gdynia, Poland

\title{
ESTIMATION OF EFFECTIVE SWATH WIDTH FOR DUAL-HEAD MULTIBEAM ECHOSOUNDER
}

\begin{abstract}
Many surveying companies and maritime institutions are now using multibeam systems for their operations, either offshore or in coastal and inland waters. Since the time the first multibeam echosounder appeared (late 1970s) the technology has advanced enormously. Modern systems now boast far greater angular coverage (typically $120^{\circ}-150^{\circ}$ ) and form hundreds of beams. Dual-head multibeam systems can potentially cover the entire sector $\left(180^{\circ}\right)$ underneath the ship. However surveyors must be aware that the outer beams of these acoustic systems return the most errors causing that the effective swath width is shorter than what the manufacturers declare. The paper presents the methods of estimating of effective (usable) swath width of dual-head multibeam echosounder EM 3002D. Results of the hydrographic survey performed by the polish navy survey ship ORP 'Arctowski' have been showed in the article.
\end{abstract}

\section{Keywords:}

multibeam echosounder, survey, swath width.

\section{INTRODUCTION}

Accurate measurement of water depth is important for the purpose of producing nautical charts in support of navigation, for monitoring underwater topography and movement of deposited sediments. Such information is also critical for port facility management and dredging operation [Gao, 2009]. Bathymetric data are 
significant to all ocean management decisions, such as identifying living and nonliving ocean resources, responding to extreme events, spatial planning, and geohazard assessment [Lucieer et al., 2016]. The demand for accurate, high resolution bathymetric maps has risen with increases in utilization of offshore resources. This demand has been met with advances in technology. Accurate positioning (better than $0,5 \mathrm{~m}$ ) of the depth measurement can now be provided by a modern satellite positioning system, which can be integrated with the appropriate navigations systems and specialized acquisition software to compile the data [Nowak et al., 2015].

There are several different methods and techniques for bathymetric measurement, which depend on the complexity of the project [Siljeg et al., 2015]. Multibeam echosounders (MBES) have been used for almost 40 years for seafloor mapping in support of chart-making, naval activities, and geoscience [Lurton, 2016]. Their ability of seafloor full coverage causes that the institutions, universities and commercial companies involved in the maritime research increasingly turn to modern, technologically advanced multibeam echosounder systems [Grządziel, Felski, 2014]. The first MBES systems appeared in the late 1970s [Renard, Allenou, 1979] with the early systems, such as the SeaBeam limited to angular coverage of $45^{\circ}$ and forming only 16 beams [Colbo et al., 2014]. Since these early echosounders, the technology has advanced enormously. Modern systems now boast far greater angular coverage (typically $120^{\circ}-150^{\circ}$ ) and form hundreds of beams. Dual-head MBES can potentially cover the entire sector $\left(180^{\circ}\right)$ underneath the ship [da Silva Pereira, 2015]. This gain in efficiency does not come without drawbacks.

Surveyors must trade-off between high data quality and minimizing survey costs. Outer beams of modern multibeam sonar systems return the most errors, as opposed to the nadir of a survey track-line. This is due, in part, to the inherently wider beams and the greater amount of time required for the outer angled pings to reach their destination and return. Other factors which degrade the precision of multibeam bathymetry, include the sound velocity, the vessel attitude, the misalignment angle of the transducer and so on. That is why hydrographer prior to the actual acquisition of sonar data has to establish design parameters for the survey. To do that surveyor needs to know what is the effective swath width of the multibeam system used for bathymetric data acquisition. This important parameter is affected by swath angle, water depth, sound velocity, temperature, salinity and bottom type. During the survey additional factors such as sea state should be considered. 


\section{METHODS}

In order to determine the effective swath width of multibeam echosounder the accuracy of depth measurement in full swath angle have been estimated. Two surfaces of the same portion of the bottom have been compared. The first bottom surface, the so-called reference surface was based on the measurements conducted with the highest possible accuracy. It was assumed that if you reduce considerably the multibeam swath angle then we can eliminate a significant part of the errors generated by outer and oblique beams. The seafloor was mapped by use of MBES working with limited swath angle. In this way reference surface of known distribution of depth has been achieved. Unfortunately, there is not indeed such ideal surface of the bottom without measuring errors, however, the surface obtained in this way is characterized by the smallest measurement uncertainties.

Next, the survey of the same portion of the bottom has been performed by means of multibeam echosounder working in a full swath angle, using all available acoustic beam. Survey vessel sailed through the center of the tested area with simultaneous registration of depth data. Research was conducted in five test sites of different depth ranging from 12 meters to 101 meters. Swath angle of the MBES and line spacing varied depending on test site.

Before the beginning of measurement survey vessel drifted and sound speed profile was taken by means of CTD device. Then the profile was imported to QINSy ver. 8.10. Bathymetric data acquired during the research were checked, processed and validated, outliers and erroneous data removed. Sea level corrections were applied as well. Finally sounding grid was generated. Then two bottom surfaces were compared. We analyzed data from several lines crossing both surfaces and the differences of depth measurements were estimated. In the next step these depth differences were averaged in full available swath angle and presented as a function of swath width and beam steering angle. Such a presentation of results allows to visually assess the change in data quality depending on the swath angle accepted in hydrographic survey.

\section{Test sites}

Research was conducted in five sites of different depth within southern eastern Baltic. The bottoms of the areas were relatively flat and leveled. The first test site featured depths ranging from $11,8 \mathrm{~m}$ to $12,5 \mathrm{~m}$ was located 18 cables from 
the southern entrance of the Gdynia port. Survey was performed on 26 November 2013. The second study area was situated 6 nautical miles East off Gdynia port, between fairways to Gdańsk port and Gdynia port. The average depth was 29 meters and the measurement was carried put on 12 March 2015. The following test was conducted on 15 January 2015 in the area of mean depth 52 meters, 3 nautical miles off Hel headland. The last two research were performed in April 2015 in the waters of 77 meters depth and 101 meters depth. The first site was located 16 nautical miles North of Władysławowo port, the second one within Gdańska Deep.

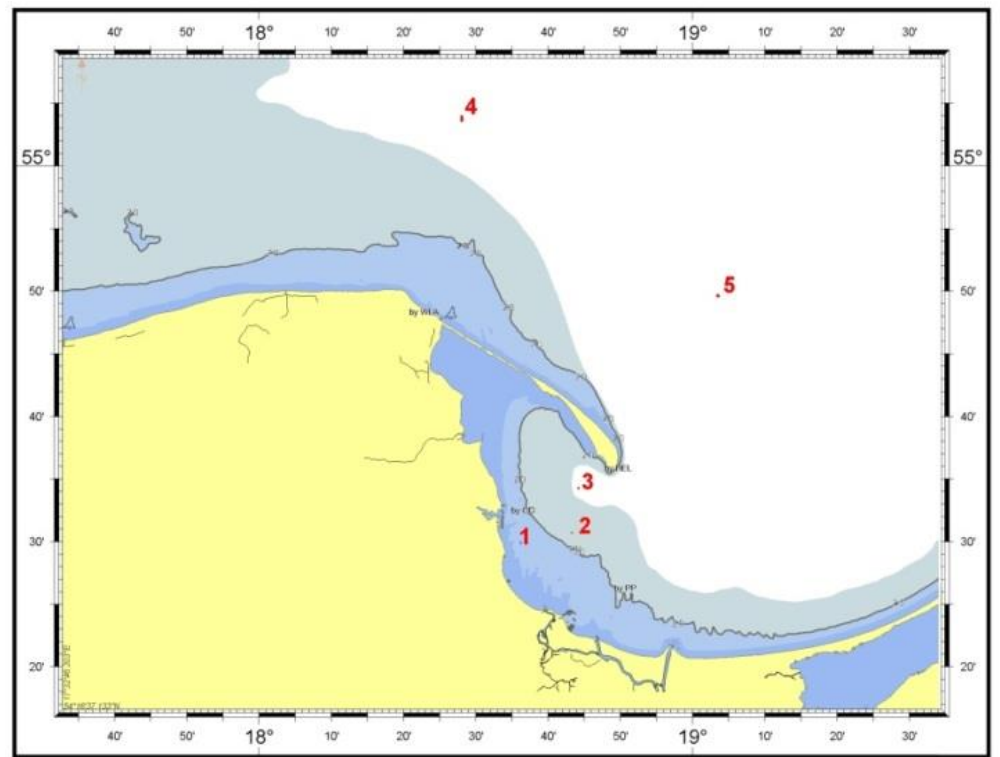

Fig. 1. Study areas of different depth: (1) area of $12 \mathrm{~m}$ depth, (2) area of $29 \mathrm{~m}$ depth, (3) area of $52 \mathrm{~m}$ depth, (4) area of $77 \mathrm{~m}$ depth, (5) area of $101 \mathrm{~m}$ depth

\section{Equipment used}

Survey was conducted from the hydrographic survey ship ORP 'Arctowski' All the tests were performed in favorable hydro meteorological conditions, with maximum sea state 1-2 and wind 2-3B. Dual head multibeam echosounder Kongsberg EM 3002D was used in the study. The EM 3002D multibeam echo sounder is a very high resolution seabed mapping and inspection system meeting the most demanding standards for survey accuracy. The EM 3002D system has a very high ping rate of up to $40 \mathrm{~Hz}$, a large number of measurements per ping 
(up to 254 per sonar head), $1.5^{\circ}$ beamwidth, and electronic pitch and roll stabilization. With an angular coverage sector of nominally $200^{\circ}$ (with the heads tilted $40^{\circ}$ to each side) the dual system also allows surveying to the water surface along shorelines, river banks and man-made structures. The Kongsberg EM 3002D multibeam echo sounder consists of the following units: sonar heads, Processing Unit, Operator Station.

Measurement of heading, position, roll, pitch, heave was performed by means of Seapath 300 developed specifically for the hydrographic and other high precision applications. The product combines inertial technology together with GPS satellite signals. Core components in the product are the MRU 5 inertial sensor, the Processing and HMI Unit [Kongsberg Seatex AS, 2012]. The redundancy of the Seapath measurements is improved by utilizing the two built-in GPS receivers for position and velocity determination. In case of missing data from one GPS receiver, then the other (remaining) receiver provides position and velocity, and the inertial sensor provides heading from its internal rate sensors.

For measuring a distribution of sound velocity in the water column a CTD probe was used (Midas SVX Valeport). CTD is an electronic instrument with sensors for conductivity, temperature and depth. This instrument records the salinity by directly measuring the electrical conductivity of the sea water. With the information from the CTD (salinity, temperature and pressure) it is possible to calculate the sound velocity in the water based on empirical equations.

For planning, acquisition, navigation and processing bathymetric data we took advantage of QINSy software package ver. 8.10 (Quality Integrated Navigation System) and Qloud. QINSy is used for the integration of survey sensors, display of data during navigation, data processing and sharing of survey results. QINSy Survey comes with real-time data acquisition, full survey planning, data cleaning and validation and map plotting functionality. It is easily customized with add-on modules like the MBES and SSS (Side Scan Sonar) modules. The suite of applications can be used for various types of surveys, ranging from simple single beam surveys up to complex offshore construction works.

Additionally, a Valeport miniSVS sound velocity probe mounted at the sonar head provided real-time sound speed at the transducer face during acquisition. The miniSVS data was used to calculate launch and return angle as well as phase separation of the transducer elements at the sonar head. 


\section{RESULTS}

As a result of the measurements bathymetric data sets have been obtained, which have been processed via dedicated software packages QINSy and Qloud. The results of comparison of the bottom surfaces have been shown in graphs of mean depth differences as a function of multibeam swath width (Fig. 2-6), and beam steering angle (Fig. 7). Then the effective and maximum swath width have been determined for all five depths (Tab. 1). These usable swath width are essential in the planning and execution of the hydrographic survey using multibeam echosounder.

The greatest effective swath width of $140 \mathrm{~m}$ was obtained at $87^{\circ}$ multibeam swath angle operating in the waters of a $77 \mathrm{~m}$ depth (73,2 $\mathrm{m}$ below the transducer). The lowest value of the swath width $60 \mathrm{~m}$ was found at a depth of $12 \mathrm{~m}(8,2 \mathrm{~m}$ below the transducer). At this depth the largest swath angle $150^{\circ}-160^{\circ}$ has been achieved.

Bathymetric survey at a depth of $12 \mathrm{~m}$ showed the smallest average depth differences in the entire swath width and did not exceed $10 \mathrm{~cm}$. The highest average depth differences of up to $60 \mathrm{~cm}$ values were observed in the waters with depths of $77 \mathrm{~m}$. The effective angular working sector of the multibeam echosounder that can be used during survey operation to the depths of $100 \mathrm{~m}$ is in the range of $60^{\circ}$ to $150^{\circ}$ providing efficient swath width from $60 \mathrm{~m}$ to $140 \mathrm{~m}$

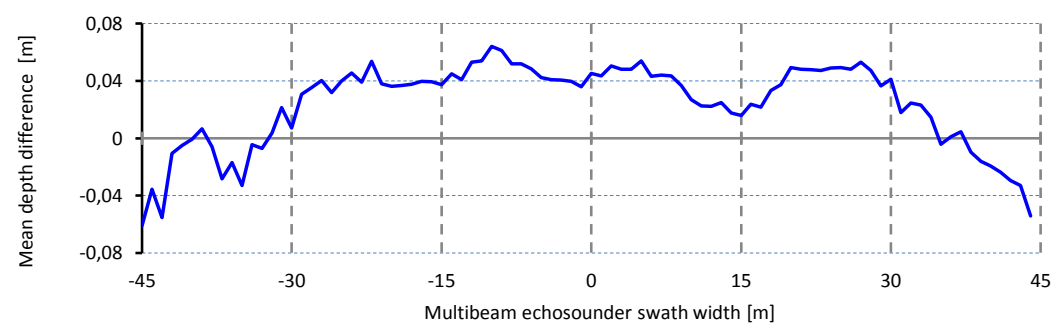

Fig. 2. Mean depth differences as a function of multibeam swath width for the area of $12 \mathrm{~m}$ depth

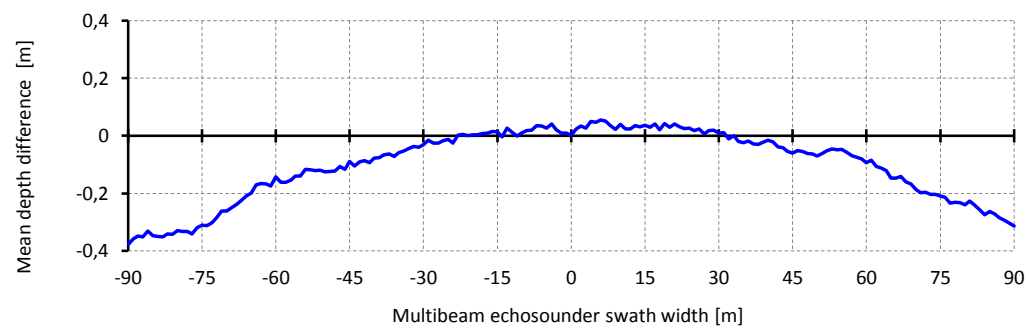

Fig. 3. Mean depth differences as a function of multibeam swath width for the area of $29 \mathrm{~m}$ depth 


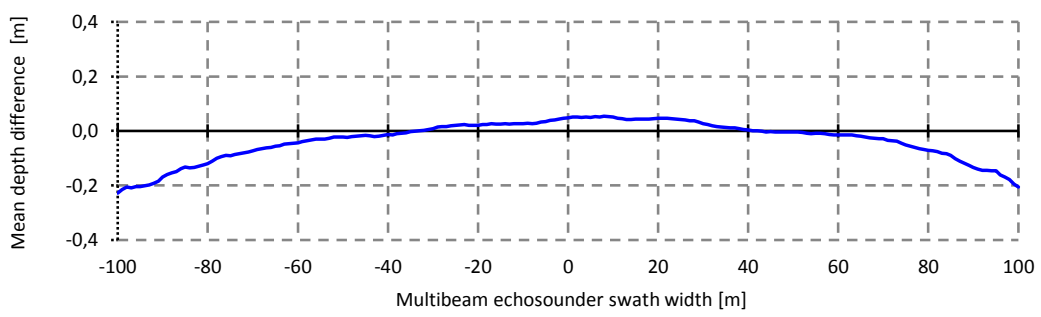

Fig. 4. Mean depth differences as a function of multibeam swath width for the area of $52 \mathrm{~m}$ depth

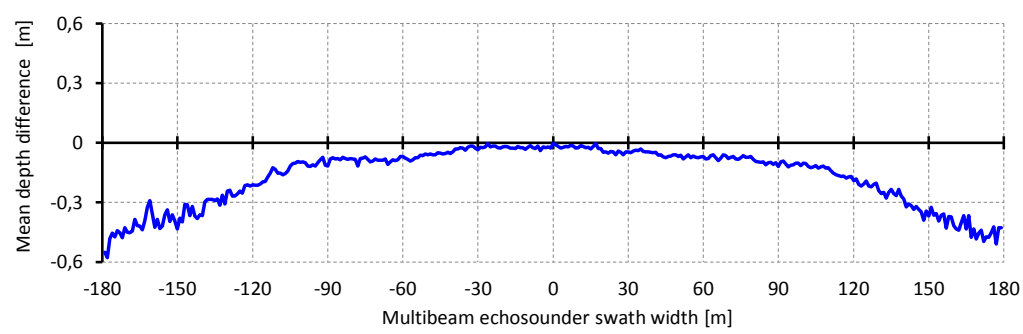

Fig. 5. Mean depth differences as a function of multibeam swath width for the area of $77 \mathrm{~m}$ depth

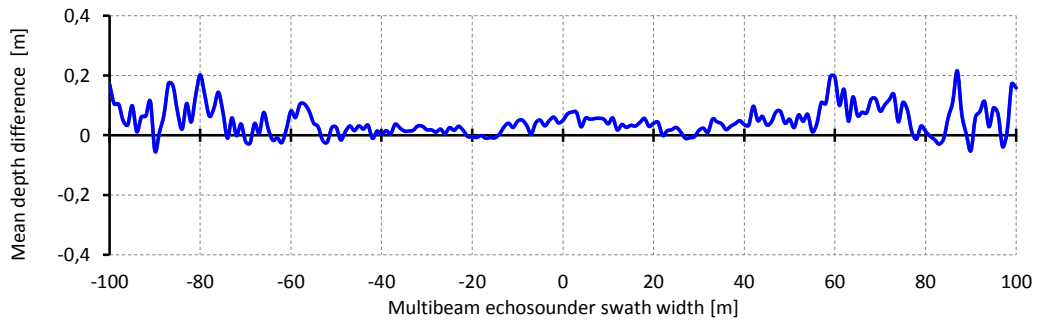

Fig. 6. Mean depth differences as a function of multibeam swath width for the area of $101 \mathrm{~m}$ depth

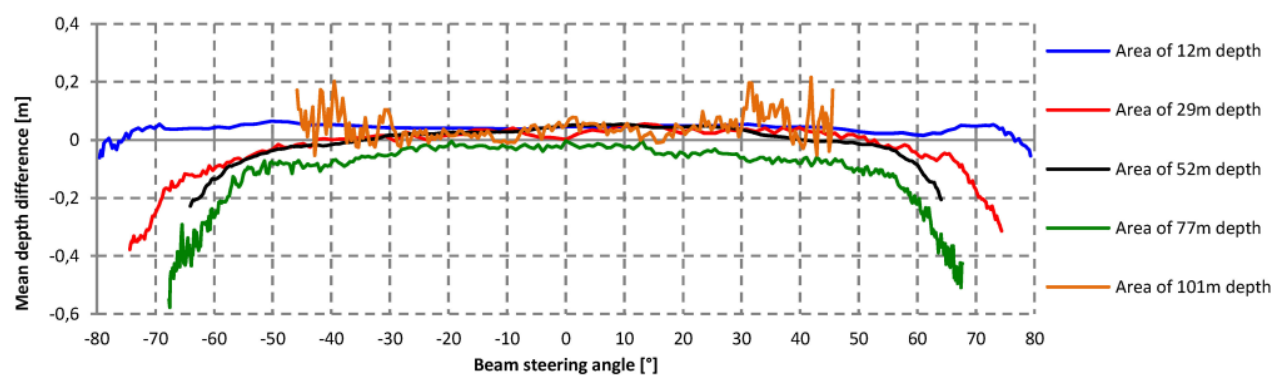

Fig. 7. Mean depth differences as function of beam steering angle for five test sites 
Tab. 1. Maximum and effective swath width and swath angle of multibeam echosounder

\begin{tabular}{|c|c|c|c|c|c|}
\hline $\begin{array}{c}\text { Depth } \\
{[\mathrm{m}]}\end{array}$ & $\begin{array}{c}\text { Depth } \\
\text { under } \\
\text { the sonar head } \\
{[\mathrm{m}]}\end{array}$ & $\begin{array}{c}\text { Max } \\
\text { swath width } \\
{[\mathrm{m}]}\end{array}$ & $\begin{array}{c}\text { Max } \\
\text { swath angle } \\
{\left[{ }^{\circ}\right]}\end{array}$ & $\begin{array}{c}\text { Effective } \\
\text { swath width } \\
{[\mathrm{m}]}\end{array}$ & $\begin{array}{c}\text { Effective } \\
\text { swath angle } \\
{\left[{ }^{\circ}\right]}\end{array}$ \\
\hline 12 & 8,2 & 90 & 160 & 60 & 150 \\
\hline 29 & 25,2 & 180 & 144 & 75 & 112 \\
\hline 52 & 48,2 & 210 & 128 & 120 & 102 \\
\hline 77 & 73,2 & 360 & 135 & 140 & 87 \\
\hline 101 & 97,2 & 200 & 90 & 110 & 59 \\
\hline
\end{tabular}

\section{DISCUSSION}

Determination of effective swath width of multibeam system that is used for regular seabed mapping is extremely important because of its practical application. Having determined values of useful swaths hydrographer is able to design the survey and make accurate calculation of the time necessary to perform the measurement operation. As a result, the commander of the survey ship or boat can accurately plan her stay at sea, which from the point of military planning requirements is significant. Parameter of effective swath width is used to determine the spacing between the survey lines and thus allows optimally design bathymetric coverage of the survey area.

Results obtained from the research slightly differ from those to be found in the manufacturer's literature [Kongsberg Maritime AS, 2005]. In this publication, the water coverage is up to ten times the water depth under the transducer. The study showed that this value may in fact be greater. An example is the survey carried out in area with depth of $12 \mathrm{~m}(8,2 \mathrm{~m}$ below the transducer) where the coverage coefficient was 10,98 . There are also differences in the maximum swath width of this echosounder model. Test results showed the convergence only at a depth of $12 \mathrm{~m}$. At depths of $29 \mathrm{~m}, 52 \mathrm{~m}$ and $101 \mathrm{~m}$ the maximum swath widths are decreased by an average of $20 \%$. The reasons for this phenomenon may be due to the long life of the transducers (over 10 years), lack of information about the actual type of bottom sediments or hydrological conditions prevailing on the waters of the south-eastern Baltic Sea. 
Noteworthy is the fact that at a depth of $77 \mathrm{~m}$ the maximum swath width of $360 \mathrm{~m}$ has been achieved, which is outside the manufacturer diagram. This result could mean that perhaps we had to deal with another type of bottom (e.g. gravel, rock) with much improved acoustic properties.

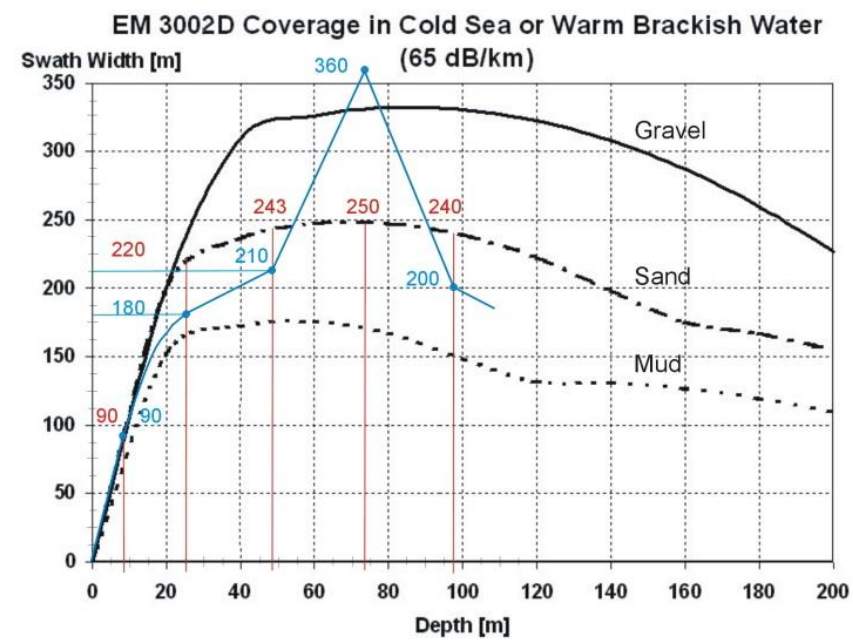

Fig. 8. Swath width of the EM 3002D echosounder [Kongsberg Maritime, 2005]; results of the research conducted in Baltic Sea condition (sand bottom) have been shown in blue colour

\section{CONCLUSIONS}

Over the last decades, multibeam echosounders have become standard in most hydrographic offices worldwide, in order to produce highest-quality navigation charts to guarantee the safety of navigation. The increased use of documents such as IHO SP44 5th edition [IHO, 2008], as standards for bathymetry acquisition has introduced the need for a greater awareness of the accuracy of measurements conducted by MBES. This is necessary both from planning perspective, establishing what portion of the swath meets the required standard and from the perspective of product delivery through a demonstration that each sounding charted meets the required specification.

The main conclusions of the study are:

1. The results of this investigation illustrate that the outer beams of multibeam echosounder produce a significant number of errors compared to the nadir 
beams. The accuracy of depth measurements is dependent on the performance of the additional sensors such as the heave-pitch-roll, sensor or vertical reference unit, the gyrocompass and sound velocity profiler, sea state as well as temporal variability of sound speed.

2. A hydrographer should be aware about the maximum and effective swath width of the multibeam echosounder he/she uses in survey operation. Depending on the swath width chosen and the depth of the survey area, depth measurements can be less or more accurate.

3. According to the study results even with the dual sonar heads, for the purpose of seabed mapping, usable angular coverage is generally limited to the range of $60^{\circ}$ to $150^{\circ}$ providing usable swath width ranging from $60 \mathrm{~m}$ to $140 \mathrm{~m}$.

4. The widest swath width may be used in order to cover the most area in the least amount of time, but only during transits or reconnaissance surveys.

5. Statistically the most effective swath angle is the average of $90^{\circ}$, which can be used at depths of $25-80 \mathrm{~m}$.

\section{REFERENCES}

[1] Colbo K., Ross T., Brown C., Weber T., A review of oceanographic applications of water column data from multibeam echosounders, 'Estuarine, Coastal and Shelf Science', 2014, Vol. 145, pp. 41-56.

[2] EM 3002 Multibeam echo sounder, Product Description, Kongsberg Maritime AS, Horten, Norway 2005.

[3] Gao J., Bathymetric mapping by means of remote sensing: methods, accuracy and limitations, 'Progress in Physical Geography', 2009, Vol. 33, Issue 1, pp. 103-116.

[4] Grządziel A., Felski A., Depth measurement accuracy for outer part of the multibeam echosounder swath width [in Polish], 'Logistyka' 2014, No. 3, CD 1, pp. 2246-2251.

[5] IHO Standards for Hydrographic Surveying, Special Publication, No. 44, 5th Edition, 2008.

[6] Lucieer V., Huang Z., Siwabessy J., Analyzing uncertainty in multibeam bathymetric data and the impact on derived seafloor attributes, 'Marine Geodesy', 2016, Vol. 39, Issue 1, pp. 32-52.

[7] Lurton X., Modelling of the sound field radiated by Multibeam echosounders for acoustical impact assessment, 'Applied Acoustics', 2016, Vol. 101, pp. 201-221.

[8] Nowak J., Rudowski S., Wróblewski R., Sitkiewicz P., Lisimenka A., Gajewski Ł., Application of a multibeam echosounder for the digital imaging of the bottom relief of seabeds and rivers, 'Bulletin of the Maritime Institute in Gdańsk', November 2015. 
[9] Renard V., Allenou J. P., Sea beam multibeam echo sounding on the Jean Charot: description, evaluation and first results, 'International Hydrographic Review', 1979, Vol. 56, pp. 36-57.

[10] Seapath 300, Precise Heading, Attitude and Positioning Sensor, KONGSBERG SEATEX AS, March 2012.

[11] Siljeg A., Lozic S., Siljeg S., A comparison of interpolation methods on the basis of data obtained from a bathymetric survey of Lake Vrana, Croatia, 'Hydrology and Earth System Sciences', 2015, Vol. 19, pp. 3653-3666.

[12] Silva Pereira D. L., Improving shallow-water multibeam target detection at low grazing angles, MSc Thesis in Engineering, The University of New Brunswick, July 2015.

Received October 2016

Reviewed December 2016

ARTUR GRZĄDZIEL

Hydrographic Support Squadron of the Polish Navy

Rondo Bitwy pod Oliwą Str., 81-103 Gdynia, Poland

ORP 'Arctowski'

e-mail: hydro.grzadziel@gmail.com

\section{MARIUSZ WĄŻ}

Polish Naval Academy

Śmidowicza 69 Str., 81-127 Gdynia, Poland

e-mail: m.waz@amw.gdynia.pl

\section{STRESZCZENIE}

Wiele biur hydrograficznych, firm komercyjnych zajmujących się pomiarami oraz instytucji i ośrodków szkoleniowych w swoich badaniach morskich i śródlądowych wykorzystuje akustyczne systemy wielowiązkowe. Od czasu pojawienia się pierwszej echosondy wielowiązkowej (lata 70. XX w.) technologia prac pomiarowych rozwinęła się na niespotykaną skalę. Nowoczesne systemy oferują dziś znacznie większe robocze kąty pracy przetworników (zazwyczaj $120^{\circ}-150^{\circ}$ ) i tworzą setki wiązek. Systemy dwugłowicowe mogą potencjalnie pracować w $180^{\circ}$ kącie roboczym pod stępką jednostki. Hydrografowie muszą mieć jednak świadomość, że skrajne wiązki tych systemów generują największe błędy, powodując, że efektywna szerokość pasa pomiarowego danej sondy jest w istocie krótsza niż ta, jaką deklarują światowi producenci. W artykule przedstawiono metodę szacowania efektywnej (użytkowej) szerokości pasa pomiarowego dwuprzetwornikowej sondy EM 3002D. Zaprezentowano wyniki badań przeprowadzonych z pokładu okrętu hydrograficznego ORP ‘Arctowski’ na akwenie Bałtyku południowo-wschodniego. 